\title{
DOSES DE FÓSFORO, ÉPOCAS DE COLETA E O CRESCIMENTO E DIAGNOSE NUTRICIONAL NOS CAPINS BRAQUIÁRIA E COLONIÃO' ${ }^{1}$
}

\author{
Carla Rossi ${ }^{2,4}$; Francisco Antonio Monteiro ${ }^{3,4 *}$ \\ ${ }^{2}$ Pós-Graduanda do Depto. de Solos e Nutrição de Plantas - ESALQ/USP. \\ ${ }^{3}$ Depto. de Solos e Nutrição de Plantas - ESALQ/USP, C.P. 9 - CEP: 13418-900 - Piracicaba, SP. \\ ${ }^{4}$ Bolsista do CNPq. \\ *e-mail: famontei@carpa.ciagri.usp.br
}

RESUMO: Foram realizados dois experimentos em solução nutritiva, um com capim-braquária (Brachiaria decumbens Stapf) e outro com capim-colonião (Panicum maximum Jacq. cv. Colonião), no período de primavera-verão. Cada experimento constou de um fatorial $3 \times 10$, no qual foram estudadas três doses de fósforo $\left(3,1 ; 15,5\right.$ e $\left.31,0 \mathrm{mg} \mathrm{L}^{-1}\right)$ e 10 épocas de coleta das plantas. $O$ delineamento adotado foi o de blocos completos ao acaso, com quatro repetições. Aos 10 dias após o início do uso das soluções nutritivas completas, iniciou-se a coleta das plantas, a qual foi repetida a cada três dias. A interação entre doses de fósforo e épocas de coleta foi significativa $(P<0,05)$ para a produção de matéria seca e a concentração de fósforo nos dois capins e para a atividade da fosfatase ácida no capim-braquiária. No início do desenvolvimento das plântulas o capim-braquiária concentrou o fósforo no tecido foliar e as doses de fósforo não alteraram a produção da planta e a atividade da fosfatase ácida nas folhas novas. A partir de dezenove dias após o transplantio a produção do capim-braquiária foi linearmente alterada pelas doses de fósforo. Para o capim-colonião a produção das plantas e a concentração de fósforo nas folhas foram substancialmente aumentadas pela maior disponibilidade de fósforo. Foram verificadas correlações negativas entre a produção da parte aérea da forrageira e a atividade da fosfatase ácida nos dois capins.

Palavras-chave: Brachiaria decumbens, Panicum maximum, concentração de fósforo, fosfatase ácida

\section{PHOSPHORUS RATES, HARVEST DATES, GROWTH AND NUTRITIONAL DIAGNOSIS OF 'SIGNAL' AND ‘COLONIÃO’ GRASSES}

ABSTRACT: Two experiments were carried out in nutrient solution, one with 'signal' grass (Brachiaria decumbens Stapf.) and another with 'colonião' grass (Panicum maximum Jacq. cv. Colonião) during spring and summer seasons. The experiments consisted of a $3 \times 10$ factorial, in a randomized complete block design, with three $P$ rates $\left(3.1,15.5\right.$ and $\left.31.0 \mathrm{mg} \mathrm{L}^{-1}\right)$ and 10 harvest dates, with four replications. The results showed a significant $(P<0.05)$ interaction between $P$ rates and harvest dates with respect to dry matter yield and plant $P$ concentration for the two grasses. Sedlings of 'signal' grass concentrated $P$ in leaf tissue and $P$ rates did not change plant dry matter or acid phosphatase activity in leaves. Nineteen days after transplanting, 'signal' grass yield was linearly related to $P$ rates. Both plant dry matter and $\mathbf{P}$ concentration in young leaves of 'colonião' grass were related to increased $\mathbf{P}$ availability. A negative correlation was found between shoot yield and acid phosphatase activity for the two grasses. Key words: Brachiaria decumbens, Panicum maximum, phosphorus concentration, acid phosphatase

\section{INTRODUÇÃO}

A atividade pecuária no Brasil é principalmente voltada para os ruminantes e baseia-se no uso de pastagens nativas ou cultivadas para suprimento de nutrientes para os animais. A baixa disponibilidade de fósforo nos solos brasileiros resulta em grande prejuízo à produção das plantas de modo geral, e por reduzir o perfilhamento e retardar o desenvolvimento das gramíneas forrageiras faz com que o pasto tenha uma cobertura deficiente, abrindo espaços para espécies invasoras.

A diagnose da nutrição das plantas em fósforo é normalmente conduzida por análises químicas de tecidos da planta e pelos sintomas visuais. Esses sintomas usualmente aparecem quando não é mais possível corrigir a deficiência

${ }^{1}$ Parte da Tese de Doutorado do primeiro autor apresentado à ESALQ/USP - Piracicaba, SP. 
nutricional (Epstein, 1975). Com base nessas considerações é que se tem buscado o uso da atividade de enzimas como indicadores bioquímicos de deficiências nutricionais.

Um método alternativo para monitorar a necessidade de fósforo em culturas consiste no estudo da enzima fosfatase ácida, por ser um método rápido e geralmente sensível. A atividade de fosfatase em plantas é comumente mais elevada em condições de deficiência de fósforo que em situação de suprimento adequado. Besford (1979) sugeriu que a atividade de fosfatase tem potencial para utilização como índice bioquímico de deficiência de fósforo.

Embora a metodologia da determinação da fosfatase seja rápida e não destrutiva de toda a planta, a interpretação da relação entre atividade de fosfatase ácida e rendimento de qualquer cultura relacionada à nutrição em fósforo pode ser complicada por outros fatores, entre os quais está a idade da planta (McLachlan, 1982; Silva, 1996).

Nesse estudo objetivou-se determinar como o suprimento de fósforo e a época em que se colhe a planta interagem na produção de matéria seca e na avaliação de nutrição em fósforo por meio da concentração de fósforo e da atividade da fosfatase ácida nos capins Brachiaria decumbens e Panicum maximum.

\section{MATERIAL E MÉTODOS}

Foram realizados dois experimentos, com solução nutritiva, em casa-de-vegetação da Escola Superior de Agricultura "Luiz de Queiroz", em Piracicaba, SP, durante a primavera-verão. Em um experimento foi estudado o capim-braquiária (Brachiaria decumbens Stapf.) e no outro o capimcolonião (Panicum maximum Jacq. cv. Colonião).

Cada experimento constou de um fatorial $3 X 10$, no qual se estudaram três doses de fósforo $\left(3,1 ; 15,5\right.$ e $\left.31,0 \mathrm{mg} \mathrm{L}^{-1}\right)$ e 10 épocas de coleta das plantas (compreendidas no intervalo dos 13 aos 40 dias após o transplantio). O delineamento adotado foi o de blocos completos ao acaso, com quatro repetições.

O transplantio de onze mudas para os vasos contendo sílica realizou-se em setembro para o capim-braquiária, e em novembro para o capim-colonião, quando as plântulas atingiram um tamanho de 3 a $5 \mathrm{~cm}$ e tinham duas folhas. Os vasos possuíam capacidade para três litros e foram executados desbastes até deixar cinco plantas por vaso. Utilizou-se a solução de Sarruge (1975), com ajuste para as doses de fósforo estudadas. A renovação da solução nutritiva ocorreu a cada 15 dias, sendo o volume de um litro de solução para cada vaso completado diariamente com água deionizada.

As épocas de coleta iniciaram-se aos 13 dias após o transplantio, prosseguindo em intervalos de três em três dias. As amostragens foram destrutivas, sendo a cada três dias removidas 12 parcelas do experimento.

Para as determinações de produção de matéria seca, a planta foi dividida em parte aérea e raízes. $O$ material colhido foi secado em estufa com circulação forçada de ar a $65^{\circ} \mathrm{C}$, por um período de 72 horas. Para a avaliação da atividade de fosfatase ácida foram utilizados $100 \mathrm{mg}$ de fragmentos de $3 \mathrm{~mm}$ das lâminas de folhas novas, excluindo-se a nervura principal. Utilizou-se a metodologia descrita por McLachlan (1982), com as modificações propostas por Silva \& Basso (1993). Após a pesagem do material vegetal colhido e secado, as lâminas das duas folhas mais novas foram moídas para determinar a concentração de fósforo, com emprego da digestão nítricoperclórica, conforme metodologia descrita por Malavolta et al. (1989). A utilização das lâminas de folhas novas foram baseadas em Meirelles et al. (1988) para o capim-colonião e em Monteiro et al. (1995) para o capim-braquiária.

Os resultados dos experimentos foram submetidos à análise de variância. Efetuou-se o desdobramento da interação nos casos de significância $(P<0,05)$ e o estudo de regressões para as doses de fósforo na solução. Realizou-se o estudo de correlações entre a concentração de fósforo, produção de matéria seca e atividade de fosfatase ácida. Para a execução dessas análises utilizou-se o pacote estatístico SAS (SAS Institute, 1988).

\section{RESULTADOS E DISCUSSÃO}

\section{Produção de matéria seca}

A interação entre doses de fósforo e épocas de coleta foi significativa $(P<0,05)$ para a produção de matéria seca da parte aérea e das raízes de ambos os capins. A partir do desdobramento dessa interação foram ajustadas equações de regressão para doses de fósforo, dentro de cada época de coleta das plantas.

O efeito das doses de fósforo na produção de matéria seca da parte aérea e raízes do capimbraquária não se fez sentir nas duas primeiras épocas de coleta (13 e 16 dias após o transplantio), quando as plantas apresentavam pouco crescimento, e qualquer das doses de fós-foro (mesmo de $3,1 \mathrm{mg} \mathrm{L}^{-1}$ ), atendia a demanda das plantas. A partir 
da terceira data de coleta (19 dias após o transplantio) as plantas eram tanto mais desenvolvidas quanto mais altas as doses de fósforo (Figura 1).

Tanto a produção da parte aérea como a das raízes do capim-braquiária manteve um aumento linear com o incremento das doses de fósforo para cada época de coleta a partir dos 19 dias após o transplantio. Também Almeida (1998), ao estudar o efeito de doses de fósforo em solução, visando a produção do capimbraquiária, verificou incremento linear na produção de matéria seca da parte aérea por ocasião do primeiro crescimento desse capim.

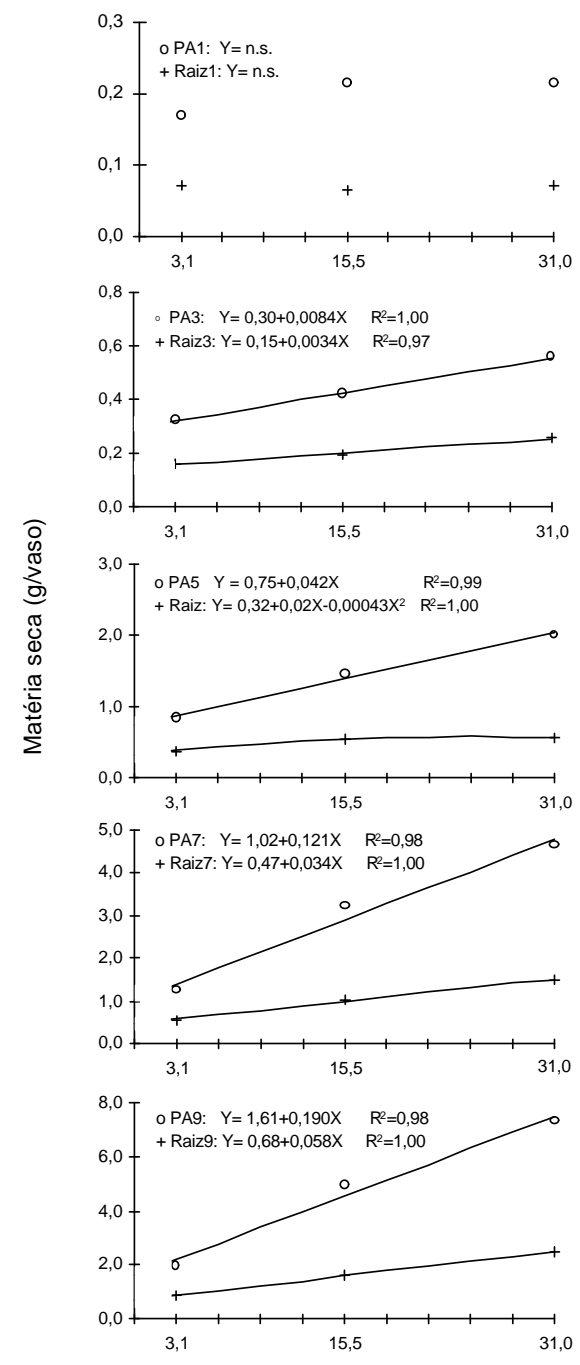

O capim-braquiária mostrou que as suas plântulas tinham sua exigência inicial em fósforo atendida por qualquer das doses do nutriente. À medida que as plantas foram se desenvolvendo e a exigência em fósforo foi se tornando maior (a fim de atender a demanda para o crescimento dessas plantas), a produção de matéria seca foi sensivelmente incrementada com as doses de fósforo. Aos 40 dias após o transplantio, as plantas crescidas na dose mais alta de fósforo apresentavam visivelmente uma produção superior às demais doses.

As repostas do capim-colonião às doses
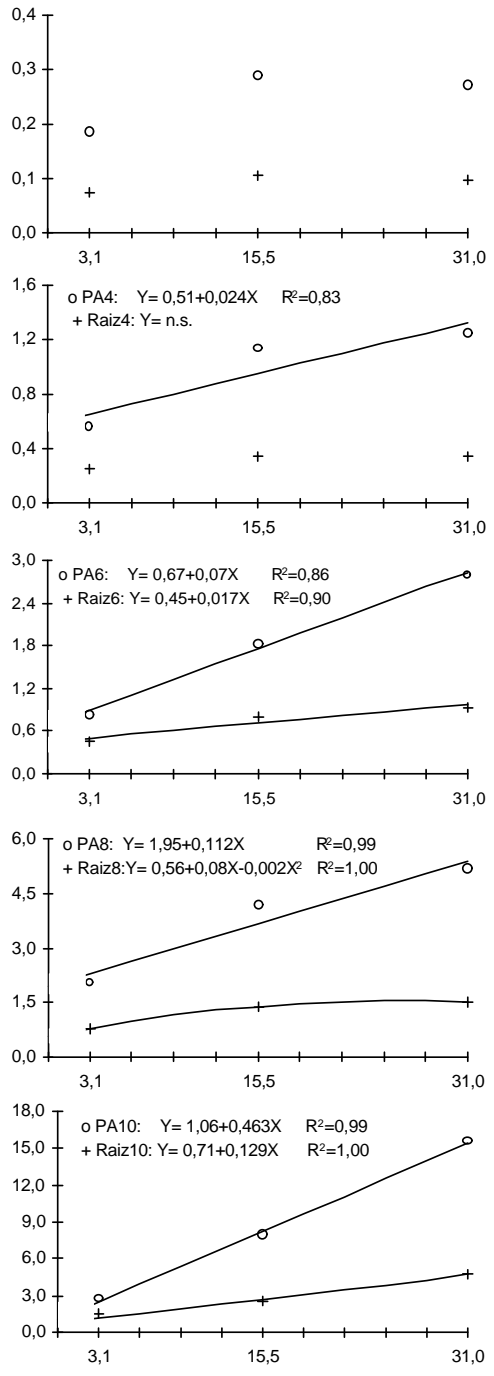

Doses de Fósforo $\left(\mathrm{mg} \mathrm{L}^{-1}\right)$

Figura 1 - Produção de matéria seca da parte aérea (PA) e raízes (Raiz) de capim-braquiária, nas épocas de coleta (1 a 10), em função das doses de fósforo na solução. 
de fósforo mostraram ajustes a modelo linear ou quadrático conforme a época de coleta considerada (Figura 2). O capim-colonião, diferentemente do capim-braquiária mostrou expressivos incrementos na produção da parte aérea e raízes, em função das doses de fósforo, já a partir das primeiras épocas de coleta. Isto indica que esse capim necessita de um bom suprimento de fósforo para atender ao seu crescimento rápido já nas fases iniciais de desenvolvimento, como verificado por Werner \& Haag (1972).

Da mesma forma que Monteiro \& Werner

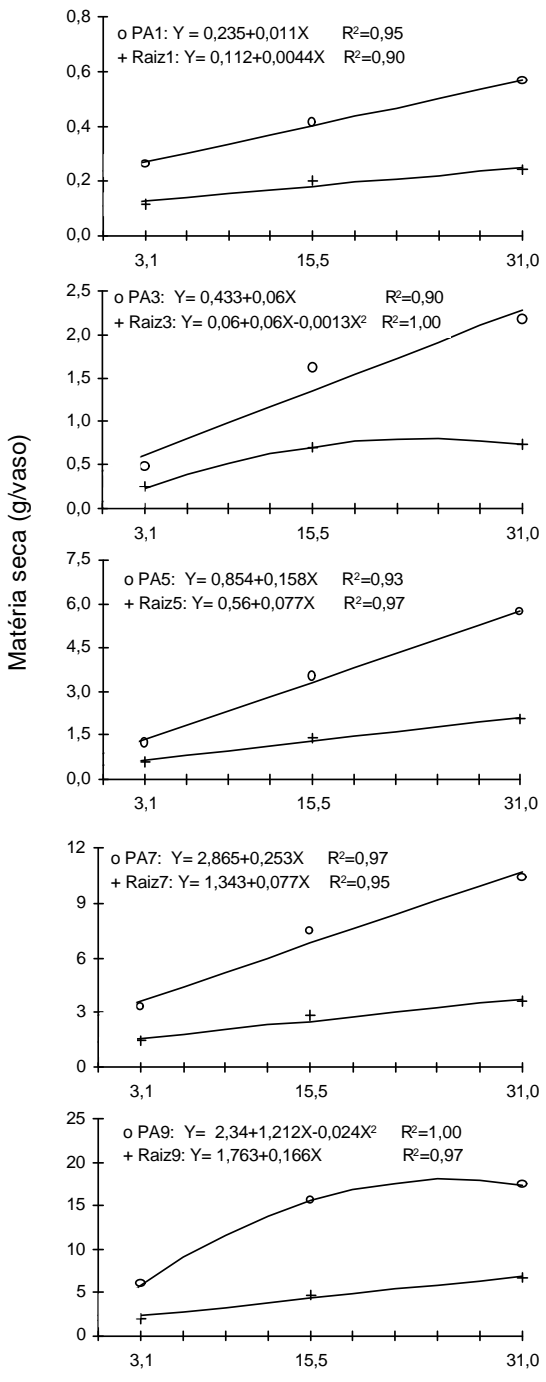

(1977), também Martinez (1980) relatou que o capim-colonião apresentou marcantes incrementos no desenvolvimento das plantas desde os estádios iniciais do experimento, em função do suprimento de fósforo.

Silva (1996) empregou doses de fósforo para o cultivar IZ-1 de Panicum maximum e verificou que a produção da parte aérea apresentou incremento linear na primeira avaliação (aos 14 dias após o transplantio), enquanto que aos 21 e aos 28 dias após o transplantio, essa produção teve ajuste a modelo quadrático.
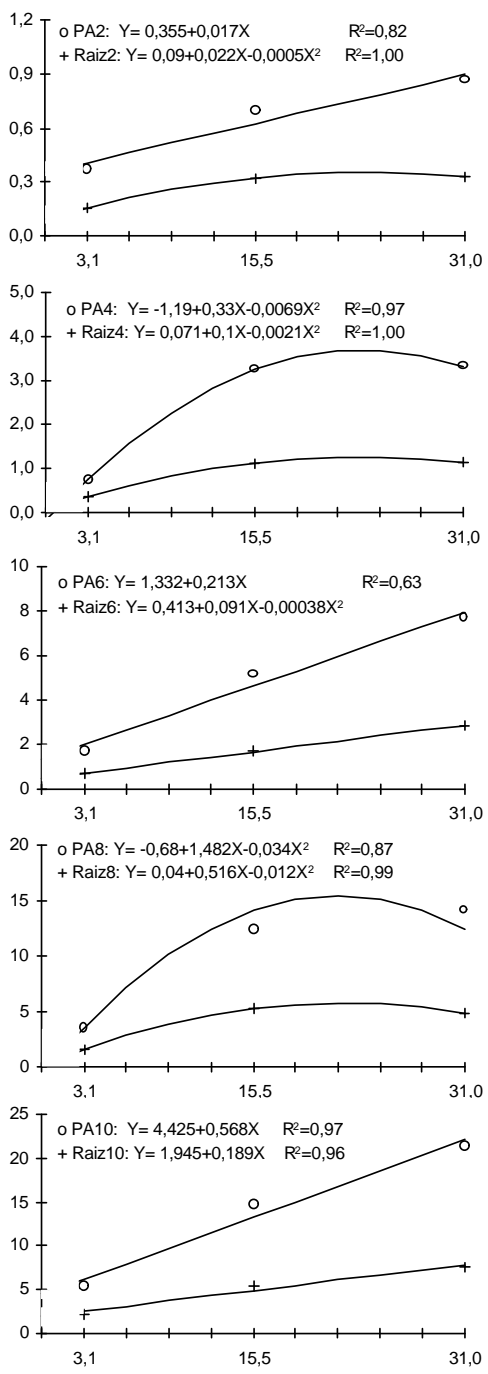

Doses de Fósforo $\left(\mathrm{mg} \mathrm{L}^{-1}\right)$

Figura 2 - Produção de matéria seca da parte aérea (PA) e raízes (Raiz) de capim-colonião, nas épocas de coleta (1 a 10), em função das doses de fósforo na solução. 


\section{Concentração de fósforo}

A análise dos resultados da concentração de fósforo nas lâminas de folhas novas de capimbraquiária e capim-colonião mostrou que a interação entre as doses de fósforo na solução nutritiva e as épocas de coleta foi significativa $(P<0,05)$.

A concentração de fósforo nas folhas de capim-braquiária variou em média de 0,7 até $6,8 \mathrm{~g} \mathrm{~kg}^{-1}$. Observa-se que houve incremento linear na concentração de fósforo no capim-braquiária com o aumento das doses de fósforo até a quarta época de coleta (aos 22 dias após o transplantio); após a qual a concentração de fósforo ajustou-se
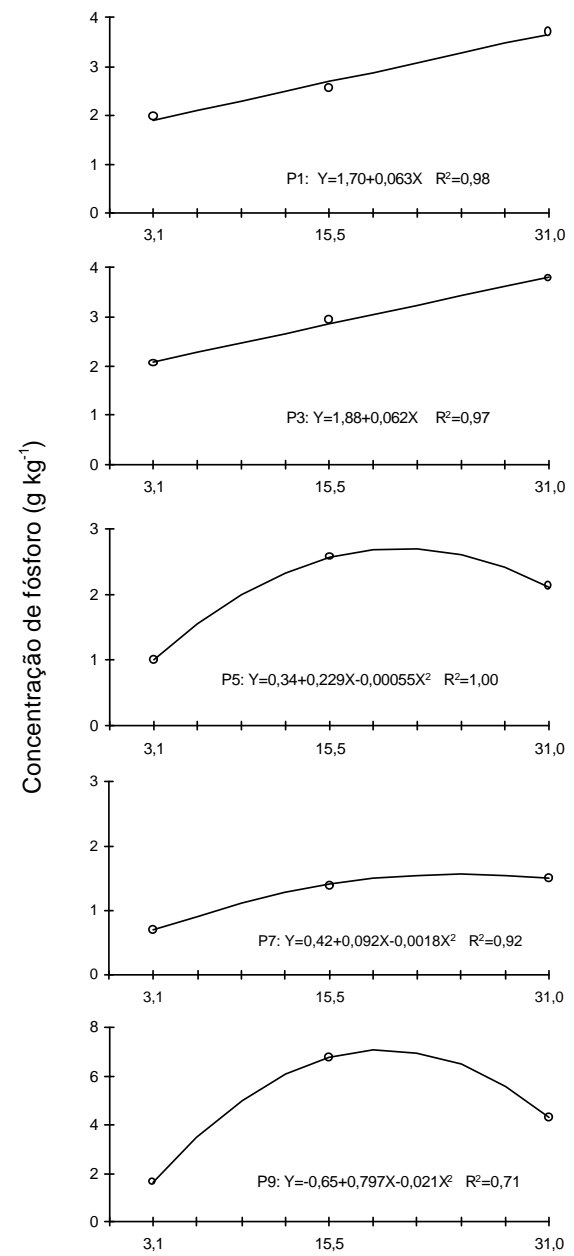

a modelo de segundo grau (Figura 3). Da quinta até a sétima coleta, a concentração de fósforo esteve muito próxima nas plantas crescidas nas doses intermediárias e mais elevada de fósforo. A partir da oitava coleta, a dose $15 \mathrm{mg} \mathrm{L}^{-1}$ apresentou concentração de fósforo mais elevada que a dose $31,0 \mathrm{mg} \mathrm{L}^{-1}$, podendo-se inferir que ocorreu efeito de diluição, uma vez que ocorreram aumentos lineares na produção de matéria seca até a mais alta dose de fósforo no substrato. Martinez (1980) também observou aumentos lineares na concentração de fósforo nas folhas de capimbraquiária, e os valores dessa concentração atingiram até $6,2 \mathrm{~g} \mathrm{~kg}^{-1}$.

A concentração de fósforo mais elevada
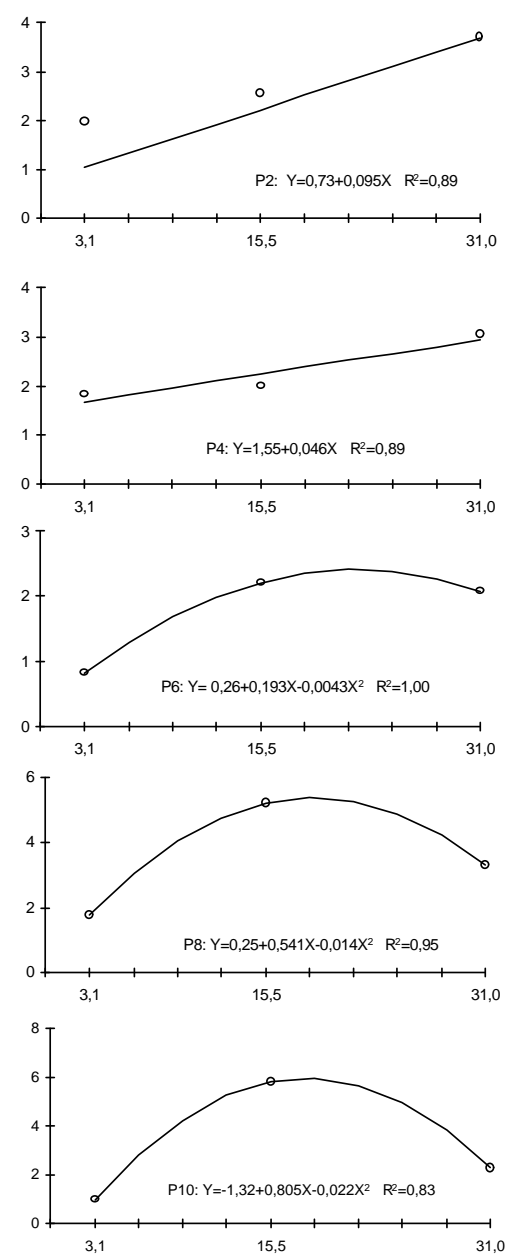

Doses de Fósforo $\left(\mathrm{mg} \mathrm{L}^{-1}\right)$

Figura 3 - Concentração de fósforo nas lâminas de folhas novas de capim-braquiária, nas épocas de coleta (1 a 10), em função das doses de fósforo na solução. 
foi obtida nos estádios finais de desenvolvimento, quando a planta estava aproximadamente há 40 dias nos vasos após o transplantio. McLachlan (1984), trabalhando com fornecimento constante de fósforo em trigo, observou que plantas mais velhas apresentaram mais elevada concentração de fósforo. A aplicação de fósforo nas várias trocas de solução possivelmente serve para explicar o incremento na concentração de fósforo na planta com a idade, uma vez que uma aplicação somente no início do experimento geralmente conduz a um decréscimo na concentração de fósforo com o
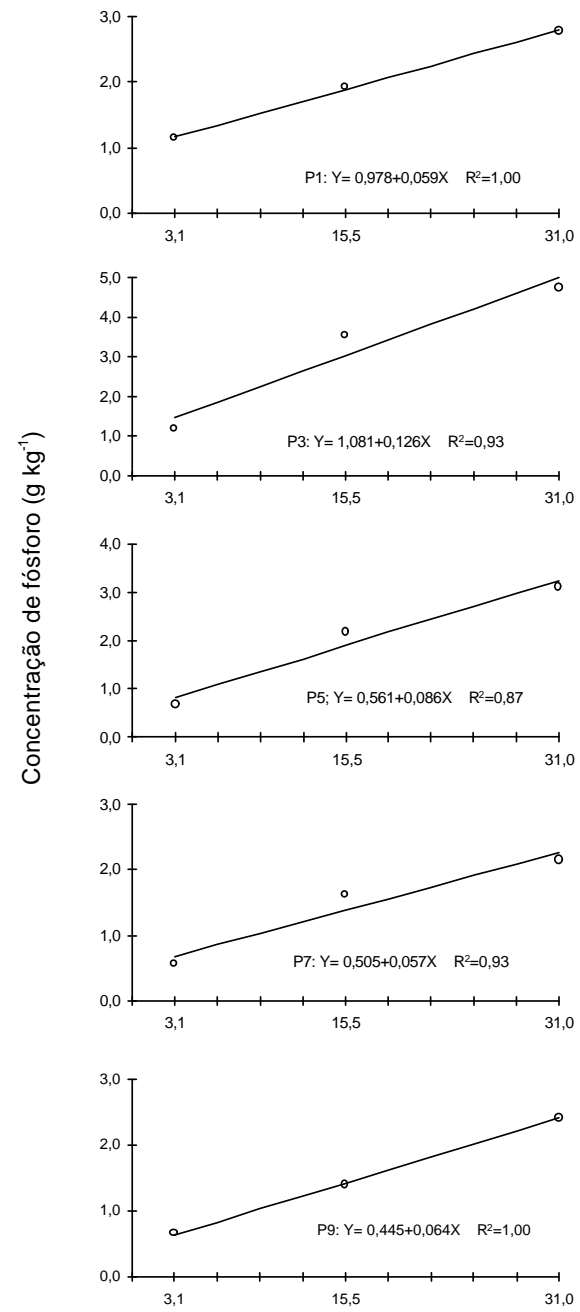

avanço da maturidade (em função da própria diluição).

Para o capim-colonião a concentração de fósforo nas folhas novas ajustou-se a modelos lineares em todas as épocas de coleta avaliadas (Figura 4). Isto está de acordo com Silva (1996) que também encontrou aumentos lineares na concentração de fósforo com incremento nas doses de fósforo para Panicum maximum cv. IZ-1, nos vários estádios de desenvolvimento da planta.

A concentração de fósforo em capim-
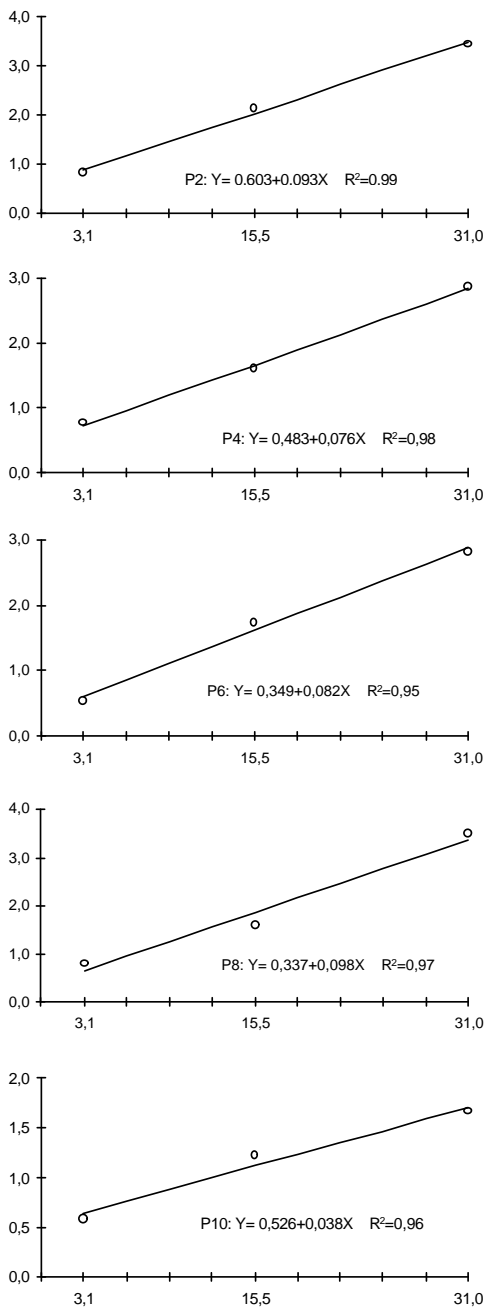

Doses de Fósforo $\left(\mathrm{mg} \mathrm{L}^{-1}\right)$

Figura 4 - Concentração de fósforo nas lâminas de folhas novas de capim-colonião, nas épocas de coleta (1 a 10), em função das doses de fósforo na solução. 
colonião variou de 0,5 a $4,75 \mathrm{~g} \mathrm{~kg}^{-1}$ sendo os valores absolutos inferiores aos observados para o capim-braquiária. A concentração de fósforo apresentou valor mais elevado nos estádios iniciais de desenvolvimento da forrageira, o que se interpreta como um efeito de concentração do nutriente no tecido vegetal, em virtude da maior produção de matéria seca do capim-colonião com o progredir da idade das plantas.

A concentração de fósforo no capimcolonião mostrou valores que estão dentro da faixa observada para essa forrageira na literatura. Essa concentração variou de 0,7 a $2,8 \mathrm{~g} \mathrm{~kg}^{-1}$ no experimento conduzido por Werner \& Haag (1972) e de 0,51 a 4,64 g kg-1 para Martinez (1980).

Pedreira \& Silveira (1972), estudando a variação na composição do capim-colonião, verificaram queda na concentração de fósforo com o avanço da idade da gramínea. Haag et al. (1967) relataram decréscimo na concentração de fósforo na haste, na folha e na planta inteira do capimcolonião com o avanço da idade das plantas (3,6 $\mathrm{g} \mathrm{kg}^{-1}$ aos 28 dias para 2,3 $\mathrm{g} \mathrm{kg}^{-1}$ aos 56 dias e aproximadamente $2,0 \mathrm{~g} \mathrm{~kg}^{-1}$ aos 84 dias de idade). Gomide et al. (1969) também constataram declínio na concentração de fósforo em capim-colonião à medida que as plantas evoluíam para a maturidade, apesar de terem recebido adequado suprimento de fósforo.

\section{Atividade da fosfatase ácida no tecido foliar}

Para atividade da fosfatase ácida em capim-braquiária foi detectada interação significativa $(P<0,05)$ entre as doses de fósforo e épocas de coleta. Não ocorreu significância $(P>0,05)$ das doses de fósforo na atividade da fosfatase por ocasião das três primeiras e na quinta época de coleta. Para as demais épocas de avaliação foram ajustadas equações de regressão de primeiro e segundo graus (Figura 5).

Elliott \& Läuchli (1986) trabalharam com milho e relataram que o efeito das doses de fósforo na atividade da fosfatase ácida dependeu da idade em que as plantas eram amostradas. Esses autores ressaltaram que a técnica não foi adequadamente sensível à deficiência moderada ou incipiente de fósforo, e que maior sensibilidade foi obtida em plantas com taxas mais elevadas de crescimento. Por sua vez, McLachlan et al. (1987) relataram que a atividade da fosfatase ácida esteve relacionada à disponibilidade de fósforo e à idade das plantas; à medida que as plantas atingiam a maturidade, o nível geral da atividade da fosfatase aumentava

De modo geral, a atividade foliar da fosfatase ácida no capim-braquiária apresentou decréscimo com o aumento das doses de fósforo, situando-se entre 37 e $21 \mu \mathrm{mol}$ $\mathrm{p}-\mathrm{NPP} \mathrm{h}^{-1} \mathrm{~g}^{-1} \mathrm{MF}$ e assemelhando-se aos valores obtidos por Press \& Lee (1983) em espécies de Sphagnum. Também Silva (1996) observou redução significativa na atividade da fosfatase ácida em capim-braquiária à medida que a concentração de fósforo na solução era aumentada.

A interação entre doses de fósforo e épocas de coleta não foi significativa $(P>0,05)$ para atividade da fosfatase ácida no capimcolonião. Essa atividade foi significativamente $(\mathrm{P}<0,01)$ afetada pelas doses de fósforo e pelas épocas de coleta independentemente. Em função das doses de fósforo ajustou-se a atividade dessa enzima a um modelo de segundo grau (Figura 6). Os valores da atividade de fosfatase encontrados localizaram-se na faixa de 24 a $31 \mu \mathrm{mol}$ p-NPP $\mathrm{h}^{-1} \mathrm{~g}^{-1}$ MF. Esses resultados são semelhantes aos determinados por Silva (1998) para vários acessos de Panicum maximum, nos quais a atividade esteve entre 26 e $40 \mu \mathrm{mol} p-N P P \mathrm{~h}^{-1} \mathrm{~g}^{-1} \mathrm{MF}$.

A faixa de variação para a atividade da fosfatase ácida encontrada no presente experimento é relativamente estreita, tornando difícil a identificação de deficiência de fósforo na cultura, a partir dessa atividade enzimática. Fernandez \& Ascencio (1994) não encontraram efeito de doses de fósforo na atividade de fosfatase ácida em feijão e caupi, contrariamente ao citado na literatura para culturas, como trigo (McLachlan, 1982), tomate (Besford, 1979), cana-de-açúcar (Silva \& Basso, 1993). Fernandez \& Ascencio (1994) apontaram que a atividade da fosfatase ácida aparentemente não seja um bom indicador de estresse de fósforo em condições de incipiente deficiência de fósforo.

\section{Correlações}

Foi efetuado o estudo das correlações entre a produção de matéria seca da parte aérea e a concentração de fósforo com a atividade da fosfatase ácida para cada época e para os valores médios de todas as épocas. Não se obteve significância $(P>0,05)$ para esses coeficientes de correlação, quando consideradas todas as épocas de corte para ambas as espécies estudadas. 
Considerando cada uma das dez épocas de coleta, verificou-se significância $(P<0,05)$ para a correlação entre a atividade da fosfatase ácida $e$ a produção de matéria seca da parte aérea em cinco épocas de coleta para o capim-braquiária e em sete delas para o capim-colonião. Quando essa atividade foi relacionada à concentração de fósforo nas folhas novas, essa significância somente foi constatada em três épocas de coleta para o capimbraquiária e em uma para o capim-colonião (TABELA 1).

McLachlan (1982), trabalhando com trigo,
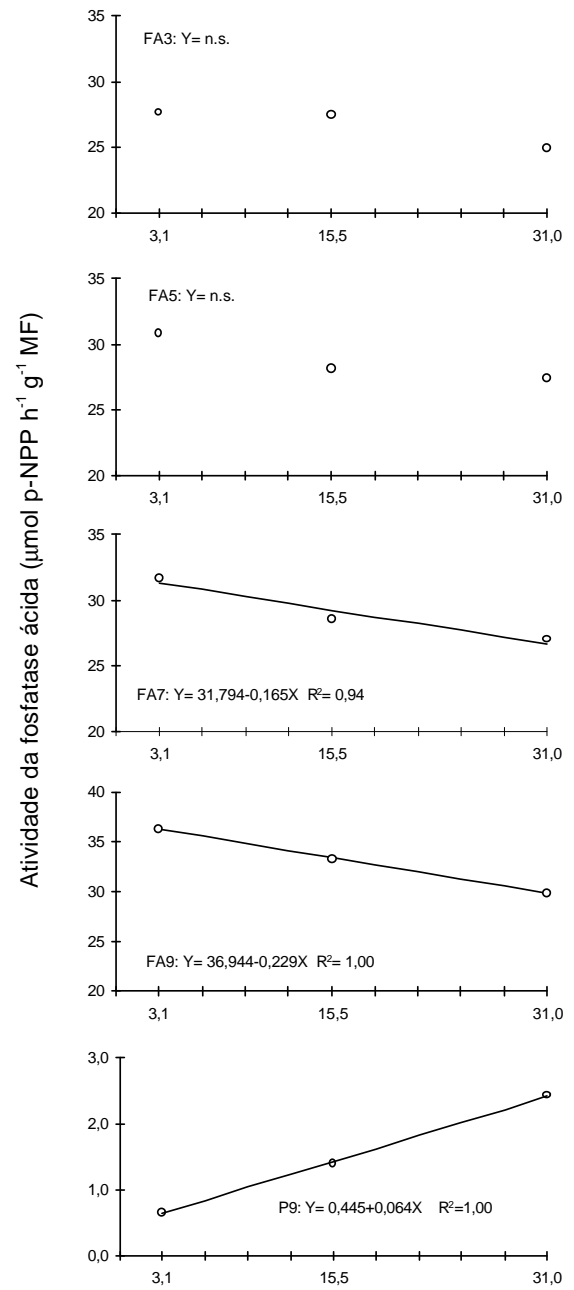

e Silva (1996), com capim-braquiária e capimcolonião, encontraram correlação significativa negativa entre atividade da fosfatase ácida e absorção de fósforo, atividade da fosfatase ácida e a concentração de fósforo no tecido vegetal, em todas as épocas de avaliação. Ainda McLachlan (1982) verificou elevada correlação entre a concentração de fósforo nas plantas de trigo e atividade da fosfatase ácida na fase inicial, sendo esta correlação menos expressiva quando do emborrachamento e não significativa na antese.
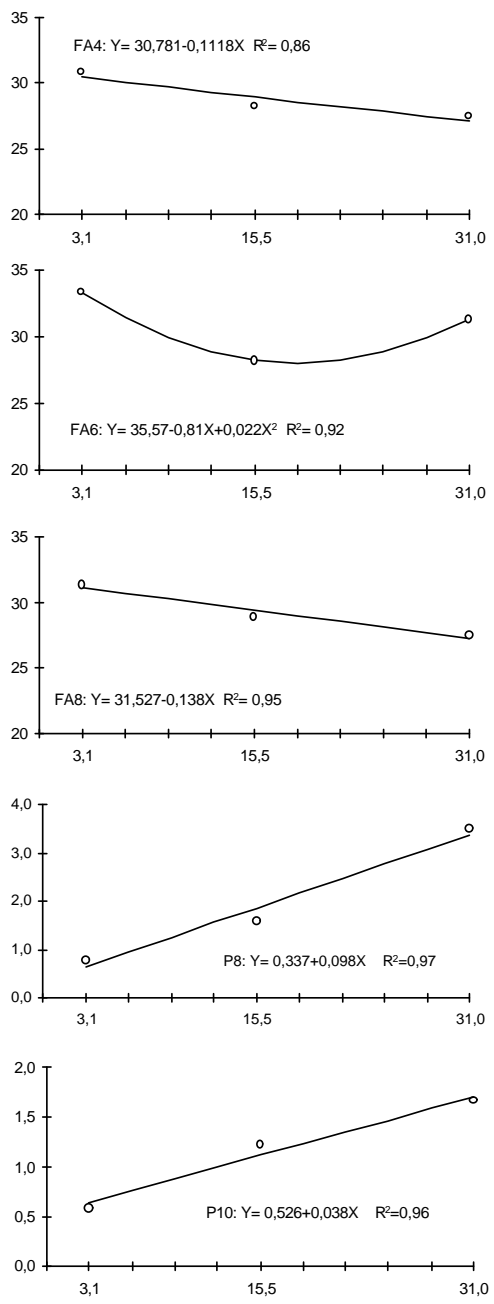

Doses de Fósforo $\left(\mathrm{mg} \mathrm{L}^{-1}\right)$

Figura 5 - Atividade da fosfatase ácida foliar de capim-braquiária, nas épocas de coleta (1 a 10), em função das doses de fósforo na solução. 
TABELA 1 - Coeficientes de correlação entre a atividade da fosfatase ácida e a produção de matéria seca da parte aérea e concentração de fósforo nas lâminas de folhas novas, em função das épocas de coleta.

\begin{tabular}{|c|c|c|c|c|}
\hline \multirow{2}{*}{$\begin{array}{c}\text { Épocas de } \\
\text { coleta }\end{array}$} & \multicolumn{2}{|c|}{ Matéria seca da parte aérea } & \multicolumn{2}{|c|}{ Concentração de fósforo } \\
\hline & Braquiária & Colonião & Braquiária & Colonião \\
\hline 1 & n.s.. & n.s. & n.s. & n.s. \\
\hline 2 & n.s. & $-0,65^{\star}$ & n.s. & n.s. \\
\hline 3 & n.s. & n.s. & n.s. & n.s. \\
\hline 4 & $-0,79^{* *}$ & $-0,76^{\star *}$ & n.s. & n.s. \\
\hline 5 & n.s. & $-0,70^{*}$ & $-0,67^{*}$ & n.s. \\
\hline 6 & n.s. & $-0,74^{\star \star}$ & $-0,75^{\star *}$ & n.s. \\
\hline 7 & $-0,93^{* *}$ & $-0,64^{*}$ & $-0,82^{* *}$ & n.s. \\
\hline 8 & $-0,75^{\star \star}$ & $-0,83^{\star *}$ & n.s. & n.s. \\
\hline 9 & $-0,68^{*}$ & $-0,88^{*}$ & n.s. & n.s. \\
\hline 10 & $-0,82^{* *}$ & n.s. & n.s. & $-0,79^{* *}$ \\
\hline
\end{tabular}

n.s., ${ }^{*},{ }^{* *}$ : não significativo, significativo a $5 \%$ e significativo a $1 \%$, pelo teste de Pearson, respectivamente.

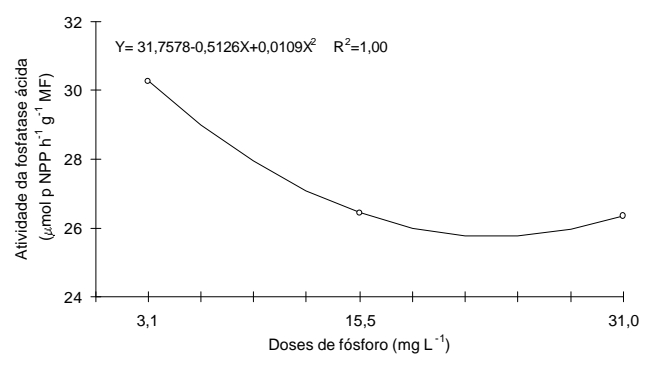

Figura 6 - Atividade da fosfatase ácida foliar de capim-colonião em função das doses de fósforo na solução.

Nos estádios iniciais de desenvolvimeto dos capins braquiária e colonião, a atividade da fosfatase ácida não foi capaz de diferenciar deficiência ou suficiência de fósforo à planta, mas em estádios de desenvolvimento mais avançados (quando a planta também começa a apresentar diferenciação na produção de matéria seca), a enzima foi capaz de contribuir na diagnose nutricional de fósforo dessa forrageira.

\section{CONCLUSÕES}

- A interação entre doses de fósforo e épocas de coleta foi significativa $(P<0,01)$ para a produção de matéria seca e a concentração de fósforo no tecido dos capins braquiária e colonião e para a atividade da fosfatase ácida do capimbraquiária.

- Até os 19 dias após o transplantio o capim-braquiária concentrou fósforo no tecido foliar e não mostrou efeito das doses do nutriente na produção da planta e a atividade da fosfatase ácida nas lâminas das folhas novas. A partir daquela época, a produção do capim-braquiária foi linearmente incrementada pelas doses de fósforo.

- O capim-colonião mostrou respostas expressivas em produção da planta e concentração de fósforo nas folhas às doses de fósforo, em cada uma das épocas de coleta.

- Exceto nas fases iniciais de desenvolvimento, os capins braquiária e colonião mostraram relação inversa entre a produção da parte aérea e a atividade da fosfatase ácida nas folhas novas, nas épocas de coleta estudadas. 


\section{REFERÊNCIAS BIBLIOGRÁFICAS}

ALMEIDA, J.C.R. de. Combinação de doses de fósforo e magnésio na produção e nutrição de duas braquiárias. Piracicaba, 1998. 81p. Dissertação (Mestrado) - Escola Superior de Agricultura "Luiz de Queiroz", Universidade de São Paulo.

BESFORD, R.T. Phosphorus nutrition and acid phosphatase activity in the leaves of seven plants species. Journal of Science Food and Agriculture, v.30, p.281-285, 1979.

ELLIOT, G.C.; LÄUCLHI, A. Evaluation of an acid phosphatase assay for detection of phosphorus deficiency in leaves of maize (Zea mays L.). Journal of Plant Nutrition, v.9, n.11, p.1469-1477, 1986.

EPSTEIN, E. Nutrição mineral de plantas: princípios e perspectivas Traduzida por E. Malavolta. Rio de Janeiro: Livros Técnicos e Científicos, 1975. 672p.

FERNANDEZ, D.S.; ASCENCIO, J. Acid phosphatase activity in bean and cowpea plants growth under phosphorus stress. Journal of Plant Nutrition, v.17, n.2-3, p.229-241, 1994.

GOMIDE, J.A.; NOLLER, C.H.; MOTT, G.O.; CONRAD, J.H.; HILL, D.L. Mineral composition of six tropical grasses as influenced by plant age and nitrogen fertilization. Agronomy Journal, v.61, n.1, p.120-123, 1969.

HAAG, H.P.; BOSE, M.L.V.; ANDRADE, R.G. Absorção dos macronutrientes pelos capins colonião, gordura, jaraguá, napier e pangola. Anais da ESALQ, v.24, p.177-188, 1967.

MALAVOLTA, E.; VITTI, G.C.; OLIVEIRA, S.A. Avaliação do estado nutricional das plantas: princípio e aplicações. Piracicaba: Potafos, 1989. $201 p$.

MARTINEZ, H.E.P. Níveis críticos de fósforo em Panicum maximum (Stapf) Prain, Brachiaria humidicola (Rendle) Schweickerdt, Digitaria decumbens Stent, Hyparrhenia rufa (Ness) Stapf, Melinis minutiflora Pal de Beauv, Panicum maximum Jacq. e Pennisetum purpureum Schum. Piracicaba, 1980. 90p. Dissertação (Mestrado) Escola Superior de Agricultura "Luiz de Queiroz", Universidade de São Paulo.

McLACHLAN, K.D. Leaf acid phosphatase activity and the phosphorus status of field-grown wheat. Australian Journal of Agricultural Research, v.33, n.3, p.453-464, 1982.

McLACHLAN, K.D. Effects of drought, aging and phosphorus status on leaf acid phosphatase activity in wheat. Australian Journal of Agricultural Research, v.35, p.777-787, 1984
MCLACHLAN, K.D.; ELLIOTT, D.E.; De MARCO, D.G.; GARRAN, J.H. Leaf acid phosphatase isozymes in the diagnosis of phosphorus status in field-grown wheat. Australian Journal of Agricultural Research, v.38, n.1, p.1-13, 1987.

MEIRELLES, N.M.F.; WERNER, J.C.; ABRAMIDES, P.L.G.; CARRIEL, J.M.; PAULINO, V.T.; COLOZZA, M.T. Níveis críticos de fósforo em capim colonião cultivado em dois tipos de solo: Latossolo Vermelho-Escuro e Podzólico Vermelho Amarelo. Boletim de Indústria Animal, v.45, n.1, p.215-232, 1988.

MONTEIRO, F.A.; WERNER, J.C. Efeitos das adubações nitrogenada e fosfatada em capim colonião, na formação e em pasto estabelecido. Boletim de Indústria Animal, v.34, n.1, p.91-101, 1977.

MONTEIRO, F.A.; MATTOS, W.T. de; MARTIM, R.A. Partes das plantas e diagnose nutricional de braquiária decumbens. In: CONGRESSO BRASILEIRO DE CIÊNCIA DO SOLO, 25., Viçosa, 1995. Resumos expandidos. Viçosa: SBCS/ UFV, 1995. p.556-557.

PEDREIRA, J.V.S.; SILVEIRA, J.J.N. Variação da composição bromatológica do capim colonião Panicum maximum Jacq. Boletim de Indústria Animal, v.29, n.1, p.185-190, 1972.

PRESS, M.C.; LEE, J. Acid phosphatase activity in Sphagnum especies in relation to phosphate nutrition. New Phytologist, v.93, n.4, p.567-573, 1983.

SARRUGE, J.R. Soluções nutritivas. Summa Phytopatologica, v.1, n.3, p.231-233, 1975.

SAS INSTITUTE. SAS user's guide: realese. 6.03 . Cary: Statistical Analysis Sistems Institute, 1988. 1028p.

SILVA, A.A. da. Toxicidade de alumínio em trinta genótipos de Panicum maximum Jacq, cultivados em solução nutritiva. Piracicaba, 1998. 146p. Tese (Doutorado) - Escola Superior de Agricultura "Luiz de Queiroz", Universidade de São Paulo.

SILVA, J.E. da. Parâmetros produtivos e atividade de fosfatase ácida em três gramíneas forrageiras cultivadas com níveis de fósforo. Piracicaba, 1996. 83p. Dissertação (Mestrado) - Escola Superior de Agricultura "Luiz de Queiroz", Universidade de São Paulo.

SILVA, F.C.; BASSO, J.C. Avaliação da atividade "in vivo" da fosfatase ácida da folha na diagnose da nutrição fosfórica em cana-de-açúcar. Revista Brasileira de Ciência do Solo, v.17, n.3, p.371-376, 1993.

WERNER, J.C.; HAAG, H.P. Estudos sobre a nutrição mineral de alguns capins tropicais. Boletim de Indústria Animal, v.29, n.1, p.191-245, 1972.

Recebido para publicação em 24.05.99

Aceito para publicação em 31.08.99 